\title{
A new species and notes on Baccharis sect. Caulopterae (Asteraceae) from Brazil
}

Uma nova espécie e notas sobre Baccharis $L$.

sect. Caulopterae DC. (Asteraceae) no Brasil

Angelo Alberto Schneider ${ }^{1}$, Gustavo Heiden $^{2}$ \& Ilsi Iob Boldrini ${ }^{1}$

\begin{abstract}
A new species of Baccharis L. sect. Caulopterae DC. (Asteraceae) from sandy soils and dunes on the coastal plain of Rio Grande do Sul state, Brazil, is presented: Baccharis dunensis A.A.Schneid. \& G.Heiden. The new species is described, illustrated and compared to more closely related species. Additionally, B. burchelli Baker is reinstated, new synonyms are proposed for B. burchellii and B. crispa Spreng., and a lectotype is designated for B. regnellii Sch.Bip. ex Baker.

Key words: Astereae, Baccharis subg. Molina, Compositae, Trimera group.

\section{Resumo}

Uma nova espécie de Baccharis L. sect. Caulopterae DC. (Asteraceae) dos solos arenosos e dunas da planície costeira do litoral do Rio Grande do Sul, Brasil, é apresentada: Baccharis dunensis A.A. Schneid. \& G.Heiden. A nova espécie é descrita, ilustrada e comparada com as espécies mais próximas. Adicionalmente, o binômio $B$. burchelli Baker é restabelecido, novos sinônimos são propostos para $B$. burchellii e $B$. crispa Spreng., e um lectótipo é designado para B. regnellii Sch.Bip. ex Baker.

Palavras-chave: Astereae, Baccharis subg. Molina, Compositae, grupo Trimera.
\end{abstract}

\section{Introduction}

Baccharis is a new world genus comprising about 360 species (Nesom \& Robinson 2007), distributed from southern Canada to southern South America (Fielding 2001; Giuliano 2001). The tufted indumentum of the leaves and stems, with adjoining basal cells of the trichomes, and the occurrence of dioecy are probably synapomorphic characters of Baccharis (Müller 2006).

Baccharis sect. Caulopterae DC. is represented by about 30 species restricted to South America (Barroso 1976; Giuliano 2001; Müller 2006) and is characterized mainly due to presence of winged stems, epaleaceous clinanthia densely covered with biseriate glandular hairs, papillose glabrous achenes, and pappus bristles of female flowers enlarged basally and fused into a ring.
During the preparation of the checklist of Brazilian species of Baccharis the description of a new species and the publication of some nomenclatural notes on Baccharis sect. Caulopterae DC. became necessary.

\section{Results and Discussion}

A new species of the coastal dunes of Rio Grande do Sul State, Southern Brazil

Baccharis dunensis A.A.Schneid. \& G.Heiden, sp. nov. Type: BRASIL. RIO GRANDEDO SUL: Capão da Canoa, entre Noiva do Mare Atlândida, 12.IV.1978, J. Pfadenhauer 250 (holotype ICN!). Fig. 1.

"Baccharis riograndensis Teodoro \& J.E.Vidal" affinis, sed alis angustioribus et pappo pluriseriato differt, similis $\mathrm{B}$. triangularis

\footnotetext{
${ }^{1}$ Universidade Federal do Rio Grande do Sul, Programa de Pós-Graduação em Botânica, Av. Bento Gonçalves 9500, 91501-970, Porto Alegre, RS, Brasil. angeloschneider@yahoo.com.br and ilsi.boldrini@ufrgs.br

${ }^{2}$ Universidade de São Paulo, Programa de Pós Graduação em Botânica, Depto. Botânica, Instituto de Biociências, R. do Matão, Tv. 14, 321,05508-900, São Paulo, SP, Brasil. gustavo.heiden@gmail.com
} 

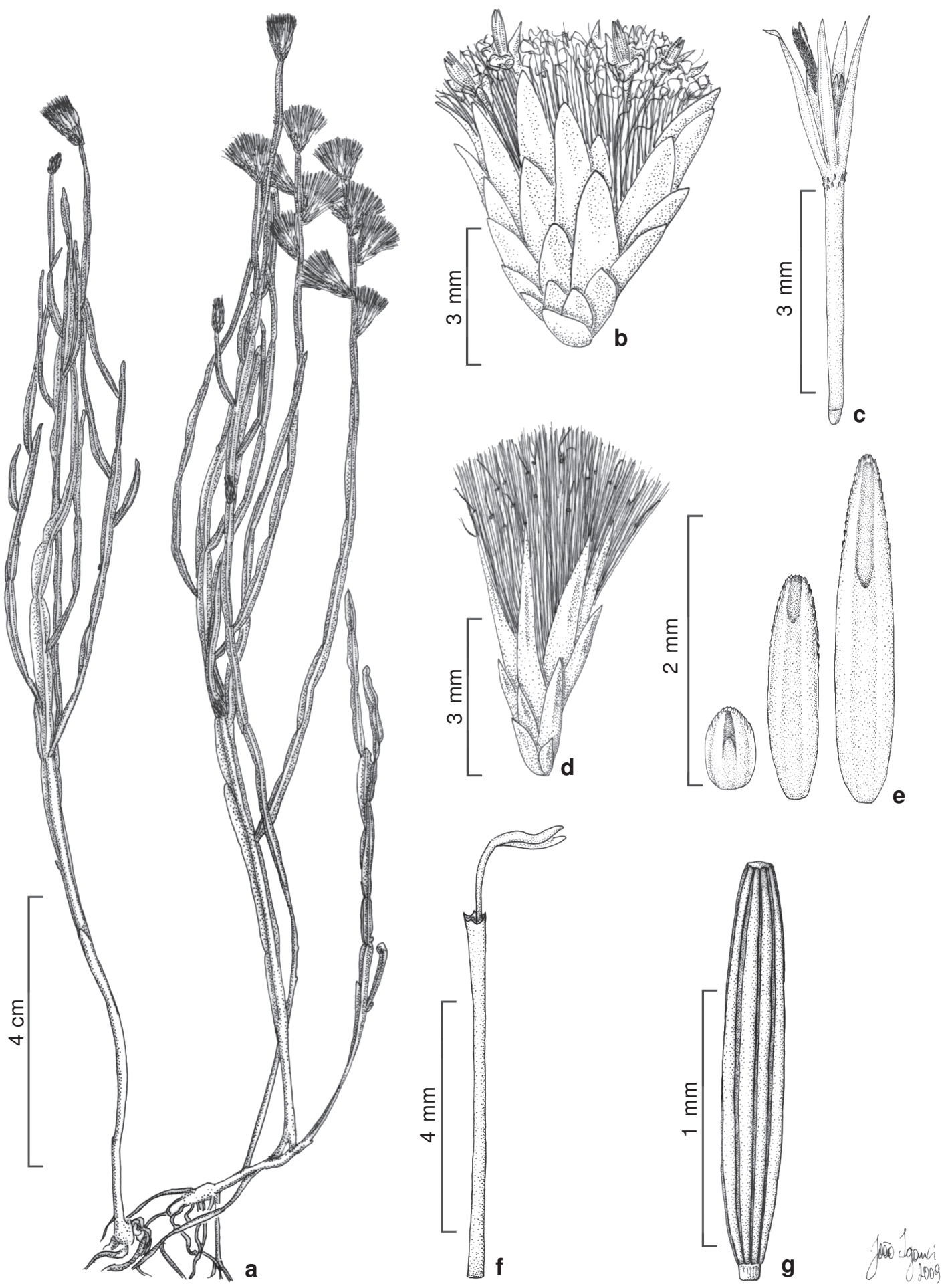

Figure 1 - Baccharis dunensis A.A.Schneid. \& G. Heiden - a. habit; b. staminate capitulum; c. staminate flower (pappus removed); d. pistillate capitulum; e. phyllaries of pistillate capitulum; f. corolla and style of pistillate flower; g. cypsela. (a, d-g Schwacke 283; b, c Heiden 1054). 
Hauman loco habitato, habitu, caule anguste alato, sed inflorescentia spiciformi et foliis apicalibus coronatis abscentibus differt.

Subshrub, 0.1-0.3 m tall; branching sympodial, shoots erect or erectopatente, ending in a capitulescence, green, resinous; stems 3winged, wings to $0.1-2 \mathrm{~mm}$ wide, plane, green, attenuate near to the nodes, internodia $0.3-2 \mathrm{~cm}$ long. Leaves squamiform, sessile, nearly triangular, 0.1-0.7 ×0.1-0.7 mm. Capitula sessile, solitary, along terminal spike-like branches $1-4 \mathrm{~cm}$ long. Male capitula 5.5-7 mm long; flowers 10-25; involucre 5-6 $\times 2-4 \mathrm{~mm}$, campanulate; phyllaries in 4 or 5 series, outermost phyllaries oblong, median phyllaries broadly lanceolate, innermost phyllaries lanceolate, all phyllaries with apex obtuse, margins yellow to light brown, broadly scarious; corolla 4-5 mm long, tube 2-3 mm long, lobes 1.5-2 mm long, coiled at maturity; style slightly exceeding the corolla, $4.5-6 \mathrm{~mm}$ long, the apex nearly fully divided into lanceolate branches, dilated towards apex, ovary abortive, glabrous and reduced; pappus uniseriate, 5-6 $\mathrm{mm}$ long, bristles 15-25, apically broadened and scarcely barbellate. Female capitula 7.5-12 mm long; flowers 10-30; involucre 7-8 $\times 1.5-2.5 \mathrm{~mm}$, cylindrical; phyllaries in 4-6 series, like those of male capitula; corolla 5$6 \mathrm{~mm}$ long, filiform, short-ligulate, the ligule denticulate, glabrous; style 6.5-7.3 mm long; cypselae $1.5-1.7 \times 0.2-0.4 \mathrm{~mm}$, nearly cylindric, epapillate; 10-12-ribbed, pappus pluriseriate to several seriate, 3.5-8 $\mathrm{mm}$ long, bristles 37-60, persistent, basally fused.

Material examined: RIO GRANDE DO SUL: Mostardas, Lagoa do Peixe, 21.II.1970, O", E. Viana et al. s.n. (ICN 7531). Rio Grande, Ilha dos Marinheiros, 29.II.1880, ㅇ, C.A.W. Schwacke 283(R); 25.V.2009, O", G. Heiden et al. 1053 (HECT, ICN, JE, K, RB). São José do Norte, I.1992, O’, P. Tagliani 77 (HURG); 10.IX.2008, G.H. Silveira \& P.C. Crespan s.n. (ICN 157830). Tavares, Lagoa do Peixe, 15.XII.1986, o, E. Danilevicz 38 (HAS). Tramandaí, 20.VIII.2005, B. Irgang s.n. (ICN 157829).

Baccharis dunensis is a small subshrub (0.1-0.3 $\mathrm{m}$ tall), with branched and narrow winged alate stems. It is likely to $B$. triangularis because both have similar habit and habitat and narrow winged stems. However, it can be distinguished from the later species mainly due the absence of a pseudoinvolucre of reduced bractlike cuneate leaves, crowded around the capitula, which are apically solitary on the fertile branches. It is also similar to $B$. riograndensis by the cylindricalelongated female capitula, but it is distinguished by the smaller tall $(0.1-0.3 \mathrm{~m}$ to $B$. dunensis and $0.3-0.6 \mathrm{~m}$ to $B$. riograndensis), the narrow wings of the vegetative branches (0.1-2 vs. $2.5-7 \mathrm{~mm}$ wide to $B$. riograndensis) and pappus several seriate.

Baccharis dunensis is probably endemic to the coastal plain of the state of Rio Grande do Sul. It is restricted to sandy soils and dunes along the coastal plain. Flowering and fruiting specimens have been collected from January to May. The conservation status was framed in VU Ba(iii)- Vulnerable, according to IUCN Red list category (IUCN 2009) because the species is known to less than 10 locations and these places are suffering intense anthropogenic pressure resulting in loss of area and decline of habitat quality, mainly due to urban expansion, dunes removal and biological invasion of coastal vegetation by exotic species such as Casuarina L. and Pinus L.

\section{Nomenclatural notes on Baccharis sect. Caulopterae from Brazil}

Baccharis burchellii Baker in Martius, Eichler \& Urban, Fl. bras. 6(3): 44. 1882. Type: BRAZIL. SÃO PAULO: "ad margine silvulae prope Morumbi", W.J. Burchell 4471 (holotype K, photo ICN!; isotype P, photo ICN!).

Baccharis regnellii var. subalata Heering in Usteri, Fl. São Paulo 258. 1911. Type: BRAZIL. SÃO PAULO: 23.XI.1906, A. Usteri 70b (holotype not found; isotype SP!), syn. nov.

Baker (1882) assigned Baccharis burchellii (ser. Caulopterae) and $B$. regnellii (ser. Oblongifoliae) in distinct series, based on the presence/abscence of winged stems and leaf shape. Barroso (1976) recognized the affinities between these species, however she considered $B$. burchellii as a synonym of $B$. regnellii var. subalata Heering. In the current work, $B$. burchellii was considered as a distinct species and its name has been applied based on their studied types and recent collections. Baccharis burchellii is morphologically related to $B$. regnellii, but it can be distinguished mainly by the winged stem and sessile leaves with entire margins (vs. stem apterous and leaves with petiole and crenulate margins in $B$. regnellii). 
Baccharis crispa Spreng., Syst. veg. 3: 466. 1826. Molina crispa (Spreng.) Less., Linnaea 6: 141. 1831. Baccharis genistelloides var. crispa (Spreng.) Baker in Martius, Eichler \& Urban, Fl. bras. 6(3): 41. 1882. Pingraea crispa (Spreng.) F.H.Hellw., Candollea 46: 217. 1993. Baccharis genistelloides subsp. crispa (Spreng.) Joch.Müll., Syst. Bot. Monogr. 76: 198. 2006. Type: Uruguay, Montevideo, 1821-1822, O', F. Sellow d397 [M.I.B. 736] (holotype P, photo ICN!; isotypes BR; G; G-DC; R!, W).

Baccharis subcrispa Teodoro, Contr. Inst. Geobiol. 8:39. 1957. Type: BRAZIL. RIODEJANEIRO: Pedra do Altar, A.C. Brade 15593 (holotype RB!; isotypes ICN!, JE!), syn. nov.

Barroso (1976) considered Baccharis subcrispa as synonym of B. opuntioides Mart. ex Baker, an endemic species to the Serra do Caparaó (ES/MG). However, based on the analysis of the holotype of $B$. subcrispa, we ascertain this name as conspecific to $B$. crispa due its morphological congruence.

Baccharis regnellii Sch.Bip. ex Baker in Martius, Eichler \& Urban, Fl. bras. 6(3): 74. 1882. Type: BRAZIL. MINAS GERAIS: Poços de Caldas, 9.IX.1867, ㅇ, A.F. Regnell II-155. (lectotype R!, here designated; duplicates BR, photo ICN!; C, photo ICN!; US, photo ICN!).

Baker (1882) described Baccharis regnellii listing two specimens (Regnell II.155 and Glaziou 7718 ). During the revision of herbarium $\mathrm{R}$, a duplicate of the gathering Regnell II.155 (R) was found. This specimen is designated here as lectotype, due its congruency with the original description and by representing a fertile branch with developed capitula and flowers.

\section{Acknowledgements}

The authors are grateful to the herbaria curators, to the collectors of the studied specimens, to CAPES and CNPq-PROTAX for the financial support of our studies, to João Iganci for preparing the illustration, to Tarciso Filgueiras for revision of the Latin diagnosis and to the anonymous reviewers for contributions on the improvement of the text.

\section{References}

Baker, J.G. 1882. Compositae. III. Asteroideae, Inuloideae. In: Martius, C.F.P. von; Eichler, A. W. \& Urban, I. (ed.). Flora brasiliensis. München, Wien, Leipzig. Vol. 6. Pp. 1-442.

Barroso, G.M. 1976. Compositae, subtribo Baccharidinae Hoffman. Estudo das espécies ocorrentes no Brasil. Rodriguésia 28: 3-273.

Fielding, R.R. 2001. Baccharis: a genus of the Asteraceae new to Canada. Proceedings of the Nova Scotian Institute of Science 41: 214-215.

Giuliano, D.A. 2001. Classificación infragenérica de las espécies argentinas de Baccharis (Asteraceae, Astereae). Darwiniana 39: 131-154.

IUCN. 2009. IUCN Red list of threatened species. Version 2009.1. Available in <http://www.iucnredlist.org > . Access on 15 November 2009.

Müller, J. 2006. Systematics of Baccharis (CompositaeAstereae) in Bolivia, including an overview of the genus. Systematic Botany Monographs 76:1-341.

Nesom, G. \& Robinson, H. [2006] 2007. XV. Tribe Astereae Cass. In: Kadereit, J. W. \& Jeffrey, C. (eds.). The families and genera of vascular plants. Kubitzki, K. (series ed.). Flowering plants: Eudicots: Asterales. Vol. VIII. Springer, Berlin. Pp. 284-342. 